\title{
What Characterizes a Fast Growing Firm?
}

by

\author{
Matthias Almus \\ Centre for European Economic Research (ZEW), Mannheim
}

\begin{abstract}
This paper seeks to empirically identify factors that influence the probability of being a fast growing firm in Eastern and Western Germany. Descriptive analyses have shown that most firms experience only small positive or negative employment growth or stagnate over time. The job generation mechanism rests with a handful of firms that increase their employment significantly over time. The empirical analysis shows that the probability of being a fast growing firm depends on different factors when separating Eastern and Western Germany as well as using different definitions of fast growing firms. Moreover, the analysis shows that technology-intensive manufacturing branches and knowledge based business related services do not generate the majority of fast growing firms.
\end{abstract}

Keywords: New Firms, Fast Employment Growth, Technology orientation.

JEL Classification: L21, C25, O39.

address: ZEW, Centre for European Economic Research,

Department of Industrial Economics and International Management

P.O.Box 1034 43, D-68034 Mannheim

phone: $\quad+49 / 621-1235-185$

fax: $\quad+49 / 621-1235-170$

E-mail: almus@zew.de 


\section{Non-technical summary:}

This paper gives an empirical contribution to the identification of factors that influence the probability of being a fast growing firm. New Eastern and Western German firms that were founded in the beginning of the 1990s are the object of examination. Descriptive analyses have shown that most firms experience only small positive or negative employment growth or stagnate over time. The job generation mechanism rests with a handful of firms that increase their employment significantly over time. The econometric analysis is based on a probit model, where the Bernoulli distributed endogenous variable indicates whether the firm belongs to the group of fast growing firms or not. The analyses account for the influence of firm-specific, founder-specific and external characteristics on the fast growth potential, while separating Eastern and Western Germany. To differentiate the effects between relative and absolute growth two definitions of fast growth serve as endogenous variables in the econometric analysis. The results of the probit analysis confirm several results of previous studies. However, various determinants influence the probability of fast growth in both Eastern and Western Germany and the definitions of fast growth in different ways. It turns out that initial size, legal form, start-up year, economic sector as well as the human capital of the firm participants influence the probability to fast growth. However, the effects mainly occur in Eastern Germany whereas the probability of rapid expansion in Western Germany is more random. Finally, the analysis shows that technology intensive manufacturing branches and knowledge based business related services do not account for the majority of fast growing firms. 


\section{Introduction}

When we talk about new firms, we often mention their potential to create additional employment or their efforts to create new and better products and services. New firms are a driving force in overcoming existing economic structures (transformation from a industrial to a service economy). Moreover, new high-tech firms in manufacturing and business related services provide new technological know-how. However, expectations that the employment created by new firms is a solution for high unemployment have been exaggerated. Various recent studies found that the employment creation potential of young firms is about $1 / 3$ in contrast to $2 / 3$ of established firms (Storey, 1994; Rajan and Zingales, 1998). These results contradict those found by Birch (1979), where new U.S. firms create the majority of employment. The Birch studies have been criticized for methodological lacks (Davis et al., 1996) but gave way to a series of empirical studies that deal with the employment creation potential of new firms and businesses (see, for Germany, Boeri and Cramer, 1991; Wagner, 1994). Another fact to be mentioned in connection with the growth aspiration of new firms is that for most start-ups employment growth is not an objective. For example, about 50 per cent of U.K. founders start their firm with no intention to grow (Storey, 1994). Looking at both the job creation potential and the relatively low propensity of new firms to grow, it is interesting to focus attention on the small number of fast growing firms that exist in every economy and to find characteristics that hamper or promote fast growth.

This study makes a methodological and explorative attempt to contribute to this line of research (the role played by fast growing firms) and close the gap which still exists between theory and practice (empirical applications). But before the empirical analysis starts we must answer the question: What is 
a fast growing firm? This question initially leads to a trade-off between the importance of absolute and relative growth rates and moreover between the growth potential of larger and smaller firms. Many studies dealing with the fast growth of firms observe the distribution of employment or sales growth and take the upper 10 per cent of the respective distribution (Storey, 1996; Lessat and Woywode, 1999; Buergel et al., 2000). This is motivated by the fact that only a few firms create the majority of employment. For example, Storey (1994) mentions that 4 per cent of the fast growing firms in his sample create about 50 per cent of the employment in this cohort over a decade. All these measures favor small firms since these must grow faster in relative terms to reach the minimum efficient scale (MES) of production in their industry that enables them to survive (Sutton, 1997). Thus, using these growth measures to identify fast growing firms would imply a bias toward small firms. A complete concentration on absolute growth measures in the change of employees on the contrary leads to a bias toward large firms.

The Birch Index (BI), a combined measure of absolute and relative growth,

$$
B I_{i}=\left(E_{1 i}-E_{0 i}\right) \frac{E_{1 i}}{E_{0 i}}
$$

with $E_{1 i}\left(E_{0 i}\right)$ as number of employees at the end (at the beginning) is used to reconcile both views (Birch, 1987). This measure still depends on firm size, but reduces the bias towards any particular firm size. The definition of fast growing firms is then similar to that of the relative growth measures. A firm is a fast growing one if it belongs to the upper 5 or 10 percentile of the Birch Index distribution.

Bruederl and Preisendoerfer (2000) take a similar approach. They combine relative and absolute employment growth to generate a group of fast growing 
firms and to weight employment creation potential with respect to firm size. A firm is defined as fast growing if it doubles its employment and creates at least additional 5 jobs within 5 years. Their descriptive analysis reveals that only about 4 per cent of the new firms qualify as "fast flyers".

The analysis mainly concentrates on the identification of factors that hamper or promote fast growth. Special attention is drawn in this context to the development in different economic sectors and different economic environments. The data set used contains firms from Eastern and Western Germany founded between 1990 and 1993. Therefore, an analysis of differences between an established social market economy and a transition and former planned economy is possible. Moreover, the probability of fast growth depends on the economic sector. Up to now, there are only a few studies that include the main economic sectors in empirical analyses. Most empirical studies concentrate on the manufacturing sector and neglect the others (Delmar, 1997). A study that includes the main economic sectors in the empirical analysis is of interest especially for Eastern Germany, since 10 years after reunification it is important to get a greater insight how firms in various economic sectors developed.

The paper proceeds as follows. After a brief description of theoretical issues in section 2, the third section deals with the data set used. Section 4 presents the descriptive analysis and definitions and the results of the econometric estimation follow in section 5. The last section provides a conclusion.

\section{Theoretical issues}

Since there is no unique theoretical model that explains the fast growth of firms, Storey‘s (1994) fast growth hypotheses as well as various theoretical 
approaches are used to model and explain fast firm growth. According to Storey three categories of factors exist which influence the probability that a firm becomes a fast growing one. These can be summarized as entrepreneurial characteristics, strategic factors and firm characteristics. I will discuss some of these and enrich them with results or considerations from other studies and approaches.

Early studies on firm growth concentrated mainly on the influence of size and age and found that small and new firms have an above average growth potential (Evans, 1987; Hall, 1987; Dunne et al., 1989). This is due to the fact that firms must reach a size that enables them to exist in the market, the so called minimum efficient size (MES). The MES varies in various economic sectors. Small firms operating in industries with a high MES should have a higher propensity to grow since crossing the MES threshold ensures that size is large enough to maintain a market preserve. Audretsch (1995) finds a positive correlation between the MES and growth for various industries. This size dependent growth potential leads to a rejection of Gibrat's law at least for small firms, according to which size should have no impact on growth (Sutton, 1997). Firms that have crossed the industry specific MES, however, should obey the law that postulates a proportional growth size relationship (Simon and Bonini, 1958). Other models emphasize the importance of learning for firm dynamics and are based on passive and active learning theoretic models derived by Jovanovic (1982) and Ericson and Pakes (1995). These approaches assume that new firms only receive information about their effectiveness after market entry, i.e. they operate in an unsure environment in the beginning, But they are able to learn from previous periods and experiences. And according to Jovanovic (1982) and Ericson and Pakes (1995), new and small firms should then grow faster, given that they survive. 
The economic conditions after German reunification offered a window of opportunity that may have favored fast growth in specific economic sectors. Firms founded in 1990 or 1991 (directly after the fall of the Berlin Wall) should therefore have a higher probability of belonging to the group of fast growing firms than those founded later on. These entrepreneurs have used their "first mover advantage", especially in Eastern Germany, to start a new firm in a niche and absorb much of the released demand potential. The effects of the start-up year are strongly connected with those emerging from belonging to different economic sectors. The construction sector and the service sector - and here primarily in Eastern Germany - should have an especially higher potential to generate fast growing firms, since there was huge unsatisfied demand after reunification. But, the economic sector dummies could also represent potential differences of the MES in economic sectors, potential market entry barriers, high entry (fixed) costs that deter entry or the availability of niches that favor fast growth.

Various studies from technology-based literature mention that increased technology as well as the knowledge orientation of the economy leads to high growth in terms of employment, sales or in the creation of new and better products and services (see the survey of Licht and Nerlinger, 1998). Firms operating in these sectors should have a higher probability to grow fast compared with firms from other branches for this reason. Since the industry classification (NACE code) of each firm in the data set is known, it is possible to separate firms from manufacturing as well as from business related services into two groups. This allows an examination of whether firms from technology intensive manufacturing industries and/or knowledge based firms from the business related services have a higher probability of becoming fast growing firms compared to 
the remaining firms (in their economic sectors). Audretsch (1995) or Almus et al. (1999), for example, find that firms in technology-intensive branches have an above average growth potential. Agarwal (1998) finds evidence that small firms that operate in a high-tech environment clearly have higher survival rates. These are indicators that such firms should also have a higher probability to grow fast. However, the specific situation in Germany after reunification could partially level out the advantages for firms in high-tech environments mentioned above. The situation in Eastern Germany especially offered firms in other economic sectors (construction, service sector trade) chances and niches to grow fast.

Firms founded with a limited liability legal form realize c.p. higher growth rates than firms in which the founder(s) are fully liable with their private assets (Stiglitz and Weiss, 1981). This is due to differences in the incentives to pursue projects that are characterized by a relatively high expected return and a relatively high risk of failure (Harhoff et al., 1998). Storey (1994) states accordingly that many studies find a tendency towards fast growth for limited companies.

Tight links with external firms may provide additional know-how or capital as well as networks with customers or suppliers (Variyam and Kraybill, 1992; Aldrich et al., 1990). Therefore, positive effects on average employment growth as well as on fast growth can be assumed from partnerships with external firms. Moreover, the human capital of the founder(s) and/or owner(s) is an important factor that determines the speed of growth. The higher the human capital endowment, the higher the probability is that a given firm is a fast growing one (Bates, 1990; Bruederl et al., 1992). Since this study can only measure the highest human capital endowment available of all persons 
involved, a team of founder(s) and/or owner(s) should more often belong to the group of firms that grow fast. This hypothesis is based on the assumption that individual know-how or knowledge deficits may be compensated for by other team members (Eisenhardt and Schoonhoven, 1990; Storey, 1994).

Several empirical studies point to the fact that location is an important factor in explaining growth (North and Smallbone, 1995). There is evidence that firms in rural areas experience more rapid growth than firms in agglomerations (Storey, 1994) since the former areas offer the firms advantages with respect to several infrastructural factors (lower rental and labor costs compared to agglomerations, better transport links).

\section{The ZEW Entrepreneurship Study}

The data set at hand is entitled ZEW Entrepreneurship Study and contains 12,000 observations that have been included in a telephone survey in 1999 (Almus and Prantl, 2000). ${ }^{1}$ About 135,000 observations from the ZEW Foundation Panel West, as well as more than 112,000 firm units from the ZEW Foundation Panel East form the parent population (Almus et al., 2000). All firms considered for drawing of the sample have an earliest start-up date between 1990 and 1993 reported by CREDITREFORM. ${ }^{2}$ These firms operate in the manufacturing, construction, trade or selected branches of the service sector and do not have the legal forms of freelance, registered society or registered cooperative. First of all, there is stratification with respect to Eastern and Western German firms - namely the sample is comprised of 6,000 firms from each region. Second, the other main stratification criterion is an indi-

\footnotetext{
${ }^{1}$ The survey is part of a project co-financed by the German National Science Foundation (DFG) and entitled "Survival, growth and fast growth of start-ups in Eastern and Western Germany".

${ }^{2}$ CREDITREFORM is the largest German credit rating agency.
} 
cator $^{3}$ that gives information as to whether the respective firm has possibly exited the market or is still active. We oversample firms with these indicators when drawing the sample to get a satisfactory number of interviews with exiting firms for the empirical analysis, since these firm groups show worse response behavior compared to firms still active on the market (Almus and Prantl, 2000).

We used a CATI system ${ }^{4}$ to carry out the survey that was divided into three stages. In the first stage, a firm representative was expected to answer the survey. Afterwards, a firm participant (owner, business manager, partner with the highest share) was chosen for all firms that did not answer the survey completely in the first stage. If no contact could be established with the selected firm participant or the person refused to answer the survey questions, a second person was chosen. With 3,702 completed interviews ${ }^{5}$ out of 12,000 sample observations, the response rate was about 31 per cent, which is relatively high compared to other German studies conducted by telephone. ${ }^{6}$

Further restrictions with respect to the date of start-up and to employment figures are necessary to obtain the data set used for the empirical analysis. The observations used for the present study had been established between 1990 and 1993. This led to the exclusion of some firms from the data set since they either had foundation dates before 1990 or after 1993 although only foundations between 1990 and 1993 should be in the sample according

\footnotetext{
3 This indicator is based on information of CREDITREFORM and points to problems in handling the data set or to different stages of bankruptcy proceedings.

${ }^{4}$ CATI stands for Computer Assisted Telephone Interviewing.

5 Representatives of surviving as well as of exiting firms took part in the survey and provided complete interviews. The term "complete interviews" refers to a final status of the CATI system. Nevertheless the individual observations differ in their information content.

${ }^{6}$ Several firms refused to answer all questions but at least gave information as to whether they had exited the market or not. For analyses dealing with the survival of firms, a statement regarding the survival status is possible for an additional 2,234 firms.
} 
to CREDITREFORM. This concerns about 800 observations. Additionally, partial and complete take-overs are excluded from the empirical analysis, since the study focuses on the fast growth potential of true or original start-ups. This concerns more than 700 firms with start-up dates between 1990 and 1993 but with some kind of economic activity prior to this date. Moreover, either surviving firms or market exits must have a valid number of employees in the year of start-up, since this is an important determinant in evaluating the employment creation process of new firms after start-up. The firms also need a further employment number at least five years after start-up to be considered for the econometric analysis. For this reason, surviving firms as well as market exits could qualify for the group of fast growing firms. Only market exits that existed for less than five years do not belong by definition to the fast growers category. Last but not least, some observations could not be used for the analysis due to missing employment numbers or missing values in exogenous variables. This leads to a final data set of 1,949 observations. Apart from the information acquired in the interviews, other details from the ZEW Foundation Panels East and West and external data bases are available.

\section{Descriptives and definition of the German high-tech sector}

\subsection{Descriptives}

Table 1 contains descriptive statistics of the main variables used in the empirical analysis. The average number of employees at start-up is about 7 whereas the median, a measure that is less suspectible to outliers, is 3 . The median confirms the findings of other studies that new firms start very small and create in most cases only a work-place for the founder(s). 
$>$ insert Table 1 about here $<<$

Moreover, Table 1 presents dummy variables containing information on the year of foundation, the industry classification and the legal form, i.e. whether they have been founded under one of the following limited-liability legal forms: GmbH or GmbH\&Co.KG (limited liability company) or Aktiengesellschaft [AG] (joint stock company). The remaining dummy variables indicate the number of persons involved in the foundation process, the highest human capital endowment of the founder(s), a dummy variable that indicates whether other firms were involved in the foundation or not as well as a variable that measures the population density in inhabitants per square kilometer.

The continuous average annual employment growth rate of firm $i$ which serves as an indicator for calculating the endogenous variable for the estimates amounts to

$$
\operatorname{growth}_{i}=\frac{\ln \left(E_{t+5_{+}}\right)-\ln \left(E_{t}\right)}{\left(t+5_{+}\right)}
$$

where $E$ represents the number of employees, $t$ the year of foundation and $\left(t+5_{+}\right)$indicates the year 5 after start-up or later on. This was done to increase the number of observations in the empirical analysis in order to decrease a sample selection bias, since several firms have incomplete employment histories. The growth rate was calculated for both surviving and exiting firms. No growth rate was calculated for market drop-outs that existed less than five years. Additionally, for the specifications of fast growing firms that combines relative and absolute growth (Birch Index and the definition by Bruederl and Preisendoerfer (2000)) of the number of jobs created in at least 5 years, it is necessary to separate firms according to their growth potential.

$$
j o b s_{i}=E_{t+5+}-E_{t}
$$


The inclusion of a growth path calculated over a period of more than five years may lead to a bias since growth rates depend on the age of the firm (Evans, 1987). The longer the observation period, the lower the annual employment growth potential. However, this problem should be of minor relevance since the calculation of growth measures exceeded the five year period only for 89 firms.

Table 2 contains additional details of the fast growing firms. Here and later on, the specification "top 10 per cent" characterizes the group of fast growing firms that belongs to the upper 10 percentile of the growth distribution for the surviving firms and the exiting firms (see equation (1)). Specification "100 per cent \& 10 jobs" represents the combined measure of doubling employment according to equation (1) and creating at least ten new jobs according to equation (2). The specification "top 10 per cent Birch Index" contains firms in the upper 10 percentile of the Birch Index distribution. 221, 197 and 193 fast growing firms belong to the three specifications, repectively. The sample was not separated with respect to Eastern and Western Germany when the fast growing firms were identified. Therefore, the analysis tries to establish those influences in Eastern and Western Germany that may have an impact on fast growth.

$>>$ insert Table 2 about here $<<$

First of all, fast growing firms in the first specification show on average the smallest start-up size. This is not surprising since this specification favors relative growth and therefore the growth of small firms. Fast growers in the first specification achieve slightly higher average annual employment growth rates. Moreover, it is not surprising that the fast growers in the second and third 
specification create slightly more jobs than the "top 10 per cent" of growing firms, since besides the relative growth criterion, firms have to create a particular number of new jobs. Finally, there are three rows in Table 2 containing the number of observations that belong to respective two specifications. This indicates that a considerable number of firms belongs to more than one fast growth specification.

\subsection{Definition of the German high-tech sector}

One goal of this paper is to examine whether firms from technology-intensive manufacturing industries as well as knowledge-based firms from the business related services have a higher probability to grow fast compared to the remaining firms in these economic sectors. The definition of technology-intensive manufacturing firms goes back to a differentiation of technology-intensive goods derived by the OECD (Gehrke et al., 1997). On the basis of this list, technologyintensive manufacturing industries have an average $R \& D$-intensity of more than 3.5 per cent. ${ }^{7}$ Recent empirical studies also found that service firms carry out a considerable amount of R\&D and innovation activities (Harhoff et al., 1996). These firms operate in so called knowledge-based business related services and the definition highlights the necessary knowledge inputs and qualification requirements for these firms to carry out innovation activities. ${ }^{8}$

However, the definitions used refer to branch averages because R\&D-intensity does not exist for the individual firms in the data set at hand. This leads to inaccuracies. On the one hand, high-tech branches have a high probability of containing firms that do R\&D to a minor extent or not at all. On the other,

\footnotetext{
7 The appendix in Nerlinger (1998) contains a list with the technology-intensive manufacturing industries.

8 Engel and Fier (2000) list in Table 1 in their appendix business related services that are knowledge-based.
} 
there are firms that carry out $\mathrm{R} \& \mathrm{D}$ in a considerable amount but belong to branches that we do not consider high-tech. Therefore, the results of the econometric estimates regarding the fast growth potential of German hightech firms should be interpreted with caution. Data sets in future analyses must contain firm specific R\&D-data to circumvent this problem. This paper is therefore a first attempt to analyze the fast growth potential of German high-tech firms.

\section{$5 \quad$ Empirical analyses}

\section{$5.1 \quad$ Model}

The point of departure for the empirical analysis are approximately 2,000 observations with complete interview information to create the endogenous and exogenous variables. The endogenous variable $y_{i}$ is Bernoulli distributed since it is either 1 (firm $i$ belongs to the group of fast growing firms) or 0 otherwise. In this case, the application of a class of models summarized by McCullagh and Nelder (1989) as Generalized Linear Models (GLM) is appropriate. This class of models tries to explain the relation

$$
E\left[y_{i} \mid x_{i}\right]=G\left(x_{i}^{\prime} \beta\right)
$$

where $x_{i}$ is a vector of exogenous variables that are interacted with a dummy variable that indicates whether the observation comes from Eastern or Western Germany. This doubles the number of exogenous variables since each exists separately for Eastern and Western Germany. Moreover, $\beta$ is the parameter vector to be estimated and $G(\bullet)$ a known link function. Assuming that the error terms $\epsilon_{i}$ in this model are normally distributed, I apply the probit model

$$
E\left[y_{i} \mid x_{i}\right]=\operatorname{Pr}\left(y_{i}=1 \mid x_{i}\right)=\operatorname{Pr}\left(x_{i}^{\prime} \beta+\epsilon_{i} \geq 0 \mid x_{i}\right)=\Phi\left(x_{i}^{\prime} \beta\right) \quad \forall i=1 \ldots N
$$


which estimates the probability that firm $i$ belongs to the group of fast growing firms where $\Phi(\bullet)$ is the cumulative density function of the standard normal.

\subsection{Specification tests and probit estimation}

Tests on normality and heteroscedasticity have been carried out to find potential misspecifications since these would lead to inconsistent estimates. I use the test procedures proposed by Verbeek (2000) to check if misspecifications of the distributional assumptions (non-normality, heteroscedasticity) exist. The results of the heteroscedasticity tests for individual variables and groups of variables are printed in Table 3. The statistics are $\chi^{2}$ distributed with as many degrees of freedom as variables to be tested for heteroscedasticity.

$>$ insert Table 3 about here $<<$

The normality assumption ${ }^{9}$ cannot be rejected at the 5 per cent level of significance in a $\chi^{2}$ test with 2 degrees of freedom for the first and third specification (see last row in Table 3). However, the null hypothesis is rejected in the specification "100 per cent \& 10 jobs".

Afterwards, we re-estimate the probit model where the variance can have the following arbitrary multiplicative form (Harvey, 1976)

$$
\sigma_{i}^{2}=\left[\exp \left(z_{i}{ }^{\prime} \alpha\right)\right]^{2}
$$

in the first and third specification, since non-normality of the error terms is not prevalent and only the human capital variables are a source of potential misspecification in both estimations (see Table 3). ${ }^{10}$ The vector $z_{i}$ contains

\footnotetext{
9 The test examines whether skewness and kurtosis are characteristic of a normal distribution.

${ }^{10}$ Unfortunately, the second specification suffers from non-normality and heteroscedasticity. Therefore, I stop using this specification and concentrate on the remaining ones, since the estimation with standard parametric methods would lead to inconsistent results.
} 
the human capital variables and equation (3) then changes to

$$
E\left[S_{i} \mid x_{i}, z_{i}\right]=\operatorname{Pr}\left(S_{i}=1 \mid x_{i}, z_{i}\right)=\Phi\left(\frac{x_{i}{ }^{\prime} \beta}{\sigma_{i}}\right) \quad \forall i=1, \ldots, N^{0}+N^{1}
$$

I tried to correct for the heteroscedasticity arising from the human capital variables using the method proposed by Harvey (1976). However, the results were unsatisfactory since the significance of the coefficient and their signs changed and some dummy variables had implausible high values. ${ }^{11}$ It turned out that heteroscedasticity seems to have a more complicated form. Therefore, I do not interpret the results from the heteroscedastic probit model but estimate additionally the first and third specification using the OLS method with robustly estimated standard errors (White, 1980). This is done since OLS generates the best linear unbiased estimator and heteroscedasticity only diminishes the efficiency. I then compared the results with those of the homoscedastic probit model (see equation (3)) and it turned out that they were nearly the same. For this reason, I present the results of the homoscedastic probit. ${ }^{12}$ The specification is just as before. Two variables exist for each determinant, one for Eastern and one for Western German firms. They are zero otherwise. This is done to make the results comparable between Eastern and Western Germany in a pooled estimation. Otherwise, one could make separate estimates for Eastern and Western Germany, restrict one coefficient to 1 and interpret the effect of other exogenous variables relative to this coefficient, since the probit model only permits an identification of the parameters up to scale. This is because of the normalization of the error terms $\epsilon_{i}$ from the normal to the standard normal distribution (McCullagh and Nelder, 1989).

Last but not least, sensitivity tests were carried out to check whether the omission of observations where the growth rates were calculated over a time

\footnotetext{
11 These results are not reported but available on request.

12 Tables 6 and 7 contain the results of the OLS estimates.
} 
period of more than five years changes the results or not. The tests showed no remarkable coefficient changes. For this reason, the interpretation of the results is based on the data set that contains all 1,949 observations.

\subsection{Results}

When interpreting the results one should keep in mind that a potential selection bias exists. Market exits have a lower probability of answering the survey questions completely and firms possessing certain characteristics are more likely to belong to the group of market exits. However, the survey yielded to a considerable number of market exits and by including the available market exit data in the analysis, the results should not suffer from the classic sample selection bias. Moreover, this potential bias diminishes due to the inclusion of firms where the growth rate was calculated for a longer period than five years.

According to the results of Delmar (1997) who reviewed 55 articles on growth, one can expect that it really matters whether the analysis concentrates on relative or on absolute growth. For this reason, I expect that the influence of the exogenous variables used in this analysis may have a different impact on the probability of fast growth for Eastern and Western Germany as well as between the relative growth measure ("top 10 per cent") and the combined fast growth measure ("top 10 per cent Birch Index"). The results appear separately for Eastern and Western Germany in Tables 4 and 5 since each determinant was interacted which leads to separate coefficients for Eastern and Western German firms.

\footnotetext{
$>>$ insert Table 4 about here $<<$

$>$ insert Table 5 about here $<<$
} 
The number of employees at start-up has the expected effect in the first specification. The smaller the firms, the higher their growth potential. This result is statistically significant at the one per cent level and indicates a deviation from Gibrat's law (Sutton, 1997). This effect does not appear for the Birch Index specification. The negative impact for the first specification is not surprising and is confirmed by numerous empirical analyses, showing that relative growth of small firms is c.p. higher than that of larger ones (Evans, 1987; Wagner, 1992; Sutton, 1997). The specification that uses the Birch Index distribution does not show this development since fast growing firms are larger here on average. The results confirm theoretical considerations that firms are founded with a suboptimal size and therefore must grow quickly to reach a MES level of production. Once this size is achieved, no compelling reasons exist for further growth in most cases (Curran, 1986; Storey, 1994). The results confirm those found in the fast growth studies of Buergel et al. (2000) or Lessat and Woywode (1999), but partially contradict those found in Bruederl and Preisendoerfer (2000). The Birch Index distribution of fast growing firms indicates a positive but insignificant growth size relation like the one found by the aforementioned authors for Bavarian business data.

Firms founded in 1992 and 1993 in Eastern Germany perform worse than firms in the reference group which where founded in 1990 in both categories. The remaining firms have the same chance of becoming fast growers. Therefore, Eastern German firms founded up to two years after reunification started in a "time window" that provided conditions favoring fast growth and offered a "first mover advantage". These firms could satisfy the increased demand for products and services since after more than 40 years of a planned economy the existing economic structures were not able to produce a sufficient amount of such necessary goods. Differences with respect to the year of start-up do not 
exist in Western Germany. Here, the year of start-up does not influence the probability of fast growth. These results, especially those for Eastern Germany, depend strongly on the development in individual branches as we will see later. The manufacturing sector released thousands of employees and a service sector hardly existed (Steiner et al., 1998). These conditions and developments favored the origin of niches in the early years following reunification. Firms that operated in these niches often had an above average growth potential in the first few years after start-up.

A further determinant of fast growth potential is the legal form. Eastern German firms with a limited liability legal form ( $\mathrm{GmbH}, \mathrm{GmbH} \&$ Co.KG, AG) have a c.p. higher growth potential. Firms with these legal forms carry out more risky projects which, if successful, result in fast growth in comparison to other firms (Stiglitz and Weiss, 1981; Harhoff et al., 1998). These differences do not appear in Western Germany where the legal form does not influence the growth potential of firms.

The effects of the sector dummies are ambiguous a priori. On the one hand, the dummies could represent the effects of different MES levels in the economic sectors under examination. On the other, the dummies could cover potential market entry barriers or high entry (fixed) costs that deter entry, as well as the existence of niches that favor fast growth. The last point mentioned is of special importance in Eastern Germany. Firms from construction, transport \& communication and business related services that are not knowledge-intensive have c.p. a higher probability of rapid growth compared with trade firms (reference sector) in the first specification in Eastern Germany. This is not surprising in view of the "construction boom" in Eastern Germany after reunification and the huge demand for services in the so called "service desert" 
of the German Democratic Republic. Moreover, this result supports the existence of niches that existed in Eastern Germany in the early 1990s. Eastern German firms from manufacturing branches that are not technology-intensive have - in addition to the three economic sectors from the first specification significantly better growth prospects in the Birch Index specification for Eastern Germany. This further supports the niche hypothesis. On the contrary, there are no sector related differences for the probability of fast growth for both specifications in Western Germany.

An important concern of this study was to establish whether firms from technology-intensive manufacturing industries as well as knowledge-based business related service firms have a higher propensity to grow fast compared to the remaining firms in these economic sectors. Eastern Germans firms operating in non-technology-intensive manufacturing sectors have better chances of becoming fast growers in comparison to firms from technology-intensive manufacturing in the Birch Index specification. This is not the case for both Western German specifications as well as for the first Eastern German specification. The special situation in Eastern Germany led to a restructuring process in the manufacturing sector (Steiner et al., 1998) and mainly new firms that do not belong to technology-intensive branches seemed to have better prerequisites to increase their number of employees substantially. The fast growth potential of this group in relative terms (high growth rates) is not surprising, since the majority of these firms is new and mostly small. Western German knowledgebased business related service firms do not have a significantly higher probability of becoming fast growers than the remaining business-related service firms. The growth prospects of these two firm groups in Eastern Germany differ since business related services that are not knowledge-intensive have a higher probability to grow fast. 
Taken together, I find no evidence that firms from technology-intensive manufacturing sectors possess a higher probability of fast growth as compared to the remaining manufacturing firms. Moreover, there is evidence that Eastern German knowledge-based business related service firms have worse chances for fast growth than than firms in the remaining business related service sectors. There are no differences between both of these firm groups in Western Germany. The results partly contradict the findings of other studies, where high-tech firms have a higher survival probability and higher average employment growth rates (Agarwal, 1998; Almus et al., 1999).

There is no significant statistical effect coming from other firms that possess a share in the founded one. Therefore, networking, financial as well as knowledge supports do not seem to favor the development of fast growers. Moreover, the probability of becoming a fast growing firm does not depend on the number of firm participants. It seems that a founding team does not offer enough advantages (e.g. compensating knowledge and/or qualification deficits) to stimulate fast growth or potential disadvantages (inconsistencies on how to run the firm) balance the advantages out.

The human capital endowment of the firm's participant(s) contributes to the explanation of fast growth. Firm participants that hold the title of doctor or professor as well as people that hold a university degree have better chances of owning firms that become fast growers. This confirms the results of Bruederl and Preisendoerfer (2000) who found that entrepreneurs with a high human capital endowment are more likely to experience fast growth. The remaining groups in the second specification and all groups in the first specification do not differ from the reference category "completed vocational training". 
Finally, the population density can only contribute to the explanation of fast growth for the Birch Index definition in Western Germany. However, the coefficients are negative for both specifications in Western and Eastern Germany. This partly supports the results of Storey (1994) and North and Smallbone (1995) that firms in rural areas experience more rapid growth than firms in agglomerations since the propensity to grow fast decreases c.p. with a rising population density.

\section{Summary}

This study focuses on determinants that favor or hamper fast employment growth of start-ups in Eastern and Western Germany founded in the first years after reunification. Special attention was paid to the development of firms in individual economic sectors and the differences between Eastern and Western Germany. Factors that favor fast growth of German firms in the 1990s exist primarily in Eastern Germany due to special conditions after reunification. The estimates have shown that the definition of fast growth has a significant influence on the impact of some exogenous variables. This indicates that it matters whether relative or absolute growth is concentrated on.

There are no signs that technology-intensive manufacturing branches and knowledge-based business related service sectors are comprised of firms that have better chances to grow fast compared with other economic sectors. Firms in technology-intensive manufacturing sectors either do not differ in their probability to or have even a smaller probability of belonging to the fast growers. The situation in knowledge-based business related services is not more favorable. Firms in these sectors in Western Germany do not perform better and in 
Eastern Germany. They perform even worse compared to the remaining firms in business related service sectors. These results may partly reflect the shortcomings in the data, since there is no firm specific information with respect to the technology-orientation of the firms available. This problem must be solved in subsequent studies.

Despite the comprehensive information in the data set at hand, the influence of other important determinants remains uncovered. Nothing is known about the characteristics and motivations of the entrepreneurs, especially in Eastern Germany shortly after reunification. Case studies of fast growing firms in this sample can shed some more light on the entrepreneur persons. Moreover, the impact of the huge number of public support schemes, especially those of the Deutsche Ausgleichsbank (DtA), to promote and support entrepreneurship after reunification have not been taken into consideration. Do these programmes have a positive effect not only on firm survival and employment growth as found by Almus and Prantl (2001), but also on the potential to grow fast?

\section{Acknowledgements}

This research has been supported by the German National Science Foundation (DFG) under the grant LE 1147/1-1. I thank Georg Licht, Josef Brderl and Dirk Czanitzki for helpful comments and Ruth Dollard for proof-reading. All errors that remain are, of course, the responsibility of the author alone. 


\section{Appendix}

Table 1: Descriptive Statistics

\begin{tabular}{|c|c|c|}
\hline variable & mean(share) & STDV \\
\hline initial size & 7.184 & 24.251 \\
\hline founded in Western Germany & 0.409 & / \\
\hline population density (inhabitants $/ \mathrm{km}^{2}$ ) & 757.971 & 1018.841 \\
\hline liability limiting legal form & 0.435 & / \\
\hline firms founded in 1990 & 0.281 & / \\
\hline firms founded in 1991 & 0.276 & / \\
\hline firms founded in 1992 & 0.237 & / \\
\hline firms founded in 1993 & 0.207 & / \\
\hline firms involved in start-up & 0.087 & / \\
\hline one person involved in start-up & 0.486 & / \\
\hline 2 to 4 persons involved in start-up & 0.490 & / \\
\hline 5 or more persons involved in start-up & 0.024 & l \\
\hline \multicolumn{3}{|l|}{ industry classification } \\
\hline manufacturing (technology-intensive) & 0.032 & / \\
\hline manufacturing (not technology-intensive) & 0.094 & / \\
\hline construction & 0.203 & / \\
\hline trade & 0.452 & / \\
\hline transport \& communication & 0.056 & / \\
\hline business rel. services (knowledge-based) & 0.095 & / \\
\hline business rel. services (not knowledge-based) & 0.061 & / \\
\hline consumption related services & 0.063 & / \\
\hline \multicolumn{3}{|l|}{ human capital endowment of founder(s) $\left.{ }^{a}\right)$} \\
\hline very high & 0.040 & / \\
\hline high & 0.410 & / \\
\hline medium & 0.302 & / \\
\hline low & 0.036 & / \\
\hline missing & 0.211 & / \\
\hline number of observation & \multicolumn{2}{|c|}{1,949} \\
\hline
\end{tabular}

Source: ZEW Foundation Panels East and West, ZEW Entrepreneurship Study.

Note: ${ }^{a)}$ Highest human capital endowment of the owner person(s) very high - Professor or Doctor $(\mathrm{PhD})$, high - university degree (Diplom), master craftsman, medium - vocational training, low - unskilled worker, missing - no details available 
Table 2: Details of Fast Growing Firms

\begin{tabular}{|c|c|c|c|c|c|c|}
\hline & \multicolumn{2}{|c|}{ top 10 per cent } & \multicolumn{2}{|c|}{$\begin{array}{l}100 \text { per cent } \\
\& 10 \text { jobs }\end{array}$} & \multicolumn{2}{|c|}{$\begin{array}{l}\text { top } 10 \text { per cent } \\
\text { Birch Index }\end{array}$} \\
\hline & \multicolumn{2}{|c|}{ group (1) } & \multicolumn{2}{|c|}{ group (2) } & \multicolumn{2}{|c|}{ group (3) } \\
\hline & mean & STDV & mean & STDV & mean & STDV \\
\hline initial size & 3.100 & 3.978 & 8.066 & 12.731 & 10.155 & 34.912 \\
\hline average annual growth rate & 0.376 & 0.099 & 0.336 & 0.133 & 0.361 & 0.128 \\
\hline absolute growth rate & 7.306 & 6.751 & 6.957 & 7.392 & 7.678 & 7.226 \\
\hline employment created & 21.484 & 26.871 & 33.470 & 36.874 & 34.047 & 37.594 \\
\hline also belonging to group (1) & \multicolumn{2}{|c|}{ / } & \multicolumn{2}{|c|}{116} & \multicolumn{2}{|c|}{137} \\
\hline also belonging to group (2) & \multicolumn{2}{|c|}{116} & \multicolumn{2}{|c|}{ / } & \multicolumn{2}{|c|}{167} \\
\hline also belonging to group (3) & \multicolumn{2}{|c|}{137} & \multicolumn{2}{|c|}{167} & \multicolumn{2}{|c|}{1} \\
\hline fast growing firms $\left(N_{1}\right)$ & \multicolumn{2}{|c|}{221} & \multicolumn{2}{|c|}{197} & \multicolumn{2}{|c|}{193} \\
\hline
\end{tabular}

Source: ZEW Foundation Panels East and West, ZEW Entrepreneurship Study. 
Table 3: Heteroscedasticity and normality tests

\begin{tabular}{lccc}
\hline & \multicolumn{3}{c}{ top $\mathbf{1 0}$ per cent } \\
\hline variable & degrees of freedom & test statistic & p-value \\
\hline industry dummies & 7 & 9.969 & 0.190 \\
start-up size & 1 & 1.246 & 0.264 \\
liability limiting legal form & 1 & 1.125 & 0.289 \\
start-up year & 3 & 2.929 & 0.403 \\
firms involved in start-up & 1 & 1.371 & 0.242 \\
persons involved in start-up & 2 & 0.006 & 0.996 \\
human capital endowment & 4 & 10.679 & $0.030^{*}$ \\
population density & 1 & 0.041 & 0.839 \\
\hline normality & 2 & 0.403 & 0.817 \\
\hline
\end{tabular}

100 per cent \& 10 jobs

\begin{tabular}{lccc}
\hline variable & degrees of freedom & test statistic & p-value \\
\hline industry dummies & 7 & 21.435 & $0.003^{*}$ \\
start-up size & 1 & 2.714 & 0.099 \\
liability lim. legal form & 1 & 4.612 & $0.032^{*}$ \\
start-up year & 3 & 6.879 & 0.076 \\
firms involved in start-up & 1 & 1.708 & 0.191 \\
persons involved in start-up & 2 & 1.484 & 0.476 \\
human capital endowment & 4 & 16.183 & $0.003^{*}$ \\
population density & 1 & 0.860 & 0.354 \\
\hline normality & 2 & 7.557 & $0.023^{*}$ \\
\hline
\end{tabular}

top 10 per cent Birch Index

\begin{tabular}{lccc}
\hline variable & degrees of freedom & test statistic & p-value \\
\hline industry dummies & 7 & 3.721 & 0.811 \\
start-up size & 1 & 3.426 & 0.064 \\
liability lim. legal form & 1 & 0.803 & 0.370 \\
start-up year & 3 & 4.272 & 0.234 \\
firms involved in start-up & 1 & 0.247 & 0.619 \\
persons involved in start-up & 2 & 1.388 & 0.500 \\
human capital endowment & 4 & 19.404 & $0.000^{*}$ \\
population density & 1 & 0.840 & 0.359 \\
\hline normality & 2 & 3.410 & 0.180 \\
\hline
\end{tabular}

Source: ZEW Entrepreneurship Study, ZEW Foundation Panels East and West.

Note: ${ }^{*}$ indicates statistical significance at the 5 per cent level in a $\chi^{2}$ test.

The variables tested were not separated for Eastern and Western Germany. 
Table 4: Homoscedastic probit estimation - top 10 per cent

\begin{tabular}{|c|c|c|c|c|}
\hline \multirow[b]{2}{*}{ variable } & \multicolumn{2}{|c|}{ Eastern Germany } & \multicolumn{2}{|c|}{ Western Germany } \\
\hline & coeff. & t-value & coeff. & t-value \\
\hline $\ln ($ start-up size $)$ & -0.488 & $-2.908^{* *}$ & -0.771 & $-2.868^{* *}$ \\
\hline $\ln (\text { start-up size })^{2}$ & -0.041 & -0.725 & 0.037 & 0.329 \\
\hline start-up in 1991 & -0.172 & -1.324 & 0.221 & 1.155 \\
\hline start-up in 1992 & -0.450 & $-3.134^{* *}$ & -0.043 & -0.202 \\
\hline start-up in 1993 & -0.381 & $-2.507^{*}$ & 0.354 & 1.787 \\
\hline liability limiting legal form & 0.719 & $4.955^{* *}$ & 0.167 & 0.921 \\
\hline manufacturing (technol.-intensive) & -0.499 & -1.005 & 0.324 & 1.018 \\
\hline manufacturing (not technol.-intensive) & 0.374 & 1.880 & 0.294 & 1.242 \\
\hline construction & 0.745 & $5.480^{* *}$ & 0.135 & 0.601 \\
\hline transport \& communication & 0.590 & $2.985^{* *}$ & 0.043 & 0.107 \\
\hline bus. rel. services (knowledge-based) & 0.035 & 0.159 & 0.175 & 0.804 \\
\hline bus. rel. services (not knowledge-based) & 0.915 & $4.206^{* *}$ & 0.194 & 0.717 \\
\hline consumption related services & -0.073 & -0.263 & $/ a)$ & / \\
\hline firms involved in start-up & -0.338 & -1.637 & 0.381 & 1.604 \\
\hline 1 person involved & 0.075 & 0.605 & 0.004 & 0.021 \\
\hline 5 or more persons involved & 0.250 & 0.760 & -0.225 & -0.439 \\
\hline very high human capital & 0.506 & 1.941 & 1.030 & $2.768^{* *}$ \\
\hline high human capital & 0.208 & 1.536 & 0.420 & $2.466^{* *}$ \\
\hline low human capital & -0.141 & -0.237 & -0.018 & -0.058 \\
\hline missing human capital & -0.129 & -0.814 & -0.281 & -1.197 \\
\hline population density & -0.010 & -0.301 & -0.052 & -1.134 \\
\hline intercept & -0.966 & $-4.131^{* *}$ & -0.966 & $-4.131^{* *}$ \\
\hline Pseudo $R^{2}$ & & & 0.152 & \\
\hline number of observations & & & 1,902 & \\
\hline
\end{tabular}

Source: ZEW Entrepreneurship Study, ZEW Foundation Panels East and West.

Note: ${ }^{* *}\left({ }^{*}\right)$ indicates statistical significance at the $1(5)$ per cent level.

a) The variable was dropped due to missing variation in the endogenous variable. 
Table 5: Homoscedastic probit estimation - top 10 per cent Birch Index

\begin{tabular}{|c|c|c|c|c|}
\hline & Easter & Germany & Wester & Germany \\
\hline variable & coeff. & t-value & coeff. & t-value \\
\hline $\ln ($ start-up size $)$ & 0.117 & 0.761 & 0.135 & 0.732 \\
\hline $\ln (\text { start-up size })^{2}$ & -0.068 & -1.697 & 0.015 & 0.369 \\
\hline start-up in 1991 & -0.100 & -0.785 & -0.020 & -0.103 \\
\hline start-up in 1992 & -0.670 & $-4.259^{* *}$ & -0.166 & -0.781 \\
\hline start-up in 1993 & -0.518 & $-3.168^{* *}$ & 0.137 & 0.718 \\
\hline liability limiting legal form & 0.531 & $3.763^{* *}$ & 0.140 & 0.789 \\
\hline manufacturing (technol.-intensive) & -0.126 & -0.321 & -0.100 & -0.256 \\
\hline manufacturing (not technol.-intensive) & 0.551 & $2.948^{* *}$ & 0.264 & 1.146 \\
\hline construction & 0.695 & $4.902^{* *}$ & -0.195 & -0.785 \\
\hline transport \& communication & 0.368 & 1.614 & 0.453 & 1.305 \\
\hline bus. rel. services (knowledge-based) & 0.235 & 1.071 & 0.121 & 0.521 \\
\hline bus. rel. services (not knowledge-based) & 0.996 & $4.597^{* *}$ & 0.325 & 1.281 \\
\hline consumption related services & 0.013 & 0.044 & -0.162 & -0.431 \\
\hline firms involved in start-up & -0.223 & -1.173 & 0.347 & 1.612 \\
\hline 1 person involved & -0.018 & -0.140 & -0.213 & -1.270 \\
\hline 5 or more persons involved & 0.384 & 1.418 & -0.154 & -0.364 \\
\hline very high human capital & 0.570 & $2.322^{* *}$ & 0.876 & $2.599^{* *}$ \\
\hline high human capital & 0.141 & 0.993 & 0.308 & 1.774 \\
\hline low human capital & 0.130 & 0.227 & 0.062 & 0.188 \\
\hline missing human capital & -0.109 & -0.610 & -0.124 & -0.495 \\
\hline population density & -0.057 & -1.588 & -0.114 & $-2.331^{* *}$ \\
\hline intercept & -1.268 & $-5.189^{* *}$ & -1.268 & $-5.189^{* *}$ \\
\hline Pseudo $R^{2}$ & \multicolumn{4}{|c|}{0.138} \\
\hline number of observations & \multicolumn{4}{|c|}{1,949} \\
\hline
\end{tabular}

Source: ZEW Entrepreneurship Study, ZEW Foundation Panels East and West.

Note: ${ }^{* *}\left({ }^{*}\right)$ indicates statistical significance at the $1(5)$ per cent level. 
Table 6: Robust OLS estimation ${ }^{a)}$ - top 10 per cent

\begin{tabular}{|c|c|c|c|c|}
\hline \multirow[b]{2}{*}{ variable } & \multicolumn{2}{|c|}{ Eastern Germany } & \multicolumn{2}{|c|}{ Western Germany } \\
\hline & coeff. & t-value & coeff. & t-value \\
\hline $\ln ($ start-up size $)$ & -0.126 & $-5.141^{* *}$ & -0.124 & $-4.584^{* *}$ \\
\hline $\ln (\text { start-up size })^{2}$ & 0.008 & 1.658 & 0.017 & $3.145^{* *}$ \\
\hline start-up in 1991 & -0.026 & -0.979 & 0.022 & 0.844 \\
\hline start-up in 1992 & -0.080 & $-2.950^{* *}$ & -0.014 & -0.568 \\
\hline start-up in 1993 & -0.068 & $-2.304^{*}$ & 0.035 & 1.360 \\
\hline liability limiting legal form & 0.138 & $4.671^{* *}$ & 0.016 & 0.766 \\
\hline manufacturing (technol.-intensive) & -0.044 & -1.112 & 0.063 & 0.987 \\
\hline manufacturing (not technol.-intensive) & 0.071 & 1.936 & 0.044 & 1.211 \\
\hline construction & 0.148 & $4.869^{* *}$ & 0.019 & 0.711 \\
\hline transport \& communication & 0.107 & $2.369^{* *}$ & 0.009 & 0.197 \\
\hline bus. rel. services (knowledge-based) & 0.012 & 0.309 & 0.026 & 0.730 \\
\hline bus. rel. services (not knowledge-based) & 0.208 & $3.532^{* *}$ & 0.020 & 0.459 \\
\hline consumption related services & 0.021 & 0.688 & -0.040 & $-2.287^{*}$ \\
\hline firms involved in start-up & -0.065 & -1.797 & 0.064 & 1.589 \\
\hline 1 person involved & 0.010 & 0.472 & 0.002 & 0.119 \\
\hline 5 or more persons involved & 0.032 & 0.496 & -0.039 & -0.563 \\
\hline very high human capital & 0.092 & 1.583 & 0.176 & $2.072^{* *}$ \\
\hline high human capital & 0.037 & 1.400 & 0.051 & $1.999^{* *}$ \\
\hline low human capital & 0.008 & 0.125 & -0.012 & -0.324 \\
\hline missing human capital & -0.023 & -0.895 & -0.035 & -1.554 \\
\hline population density & -0.002 & -0.256 & -0.009 & -1.438 \\
\hline intercept & 0.191 & $4.615^{* *}$ & 0.191 & $4.615^{* *}$ \\
\hline$R^{2}$ & \multicolumn{4}{|c|}{0.104} \\
\hline number of observations & \multicolumn{4}{|c|}{1,949} \\
\hline
\end{tabular}

Source: ZEW Entrepreneurship Study, ZEW Foundation Panels East and West.

Note: ${ }^{* *}\left({ }^{*}\right)$ indicates statistical significance at the $1(5)$ per cent level.

a) The estimation of the robust standard errors is based on White (1980). 
Table 7: Robust OLS estimation ${ }^{a)}$ - top 10 per cent Birch Index

\begin{tabular}{|c|c|c|c|c|}
\hline \multirow[b]{2}{*}{ variable } & \multicolumn{2}{|c|}{ Eastern Germany } & \multicolumn{2}{|c|}{ Western Germany } \\
\hline & coeff. & $\mathrm{t}$-value & coeff. & $\mathrm{t}$-value \\
\hline $\ln ($ start-up size $)$ & 0.006 & 0.263 & -0.005 & -0.157 \\
\hline $\ln (\text { start-up size })^{2}$ & -0.009 & -1.903 & 0.009 & 1.120 \\
\hline start-up in 1991 & -0.015 & -0.552 & -0.008 & -0.340 \\
\hline start-up in 1992 & -0.104 & $-4.201^{* *}$ & -0.022 & -0.923 \\
\hline start-up in 1993 & -0.086 & $-3.181^{* *}$ & 0.009 & 0.359 \\
\hline liability limiting legal form & 0.107 & $3.525^{* *}$ & 0.012 & 0.555 \\
\hline manufacturing (technol.-intensive) & -0.028 & -0.574 & -0.016 & -0.361 \\
\hline manufacturing (not technol.-intensive) & 0.090 & $2.211^{*}$ & 0.036 & 1.006 \\
\hline construction & 0.128 & $4.468^{* *}$ & -0.023 & -0.976 \\
\hline transport \& communication & 0.052 & 1.485 & 0.052 & 0.967 \\
\hline bus. rel. services (knowledge-based) & 0.033 & 0.808 & 0.018 & 0.600 \\
\hline bus. rel. services (not knowledge-based) & 0.205 & $3.462^{* *}$ & 0.055 & 1.204 \\
\hline consumption related services & 0.012 & 0.420 & -0.017 & -0.543 \\
\hline firms involved in start-up & -0.049 & -1.256 & 0.062 & 1.414 \\
\hline 1 person involved & -0.007 & -0.314 & -0.024 & -1.321 \\
\hline 5 or more persons involved & 0.080 & 0.952 & -0.021 & -0.253 \\
\hline very high human capital & 0.119 & 1.865 & 0.191 & $2.107^{* *}$ \\
\hline high human capital & 0.028 & 1.153 & 0.041 & 1.831 \\
\hline low human capital & 0.041 & 0.651 & 0.010 & 0.319 \\
\hline missing human capital & -0.004 & -0.193 & -0.007 & -0.345 \\
\hline population density & -0.010 & -1.545 & -0.015 & $-2.552^{* *}$ \\
\hline intercept & 0.126 & $3.398^{* *}$ & 0.126 & $3.398^{* *}$ \\
\hline Adjusted $R^{2}$ & \multicolumn{4}{|c|}{0.094} \\
\hline number of observations & \multicolumn{4}{|c|}{1,949} \\
\hline
\end{tabular}

Source: ZEW Entrepreneurship Study, ZEW Foundation Panels East and West. Note: ${ }^{* *}\left({ }^{*}\right)$ indicates statistical significance at the $1(5)$ per cent level.

a) The estimation of the robust standard errors is based on White (1980). 


\section{References}

Agarwal, R. (1998) 'Small Firm Survival and Technological Activity', Small Business Economics, 11, 215-224.

Aldrich, H., U. Staber and C. Zimmer (1990) 'Minimalism and Organizational Mortality: Patterns of Disbanding Among U.S. Trade Associations, 19001983', in J.V. Singh ed., Organizational Evolution. Newbury Park.

Almus, M., D. Engel and E.A. Nerlinger (1999) 'Wachstumsdeterminanten junger Unternehmen in den alten und neuen Bundeslaendern: Ein Vergleich zwischen innovativen und nicht-innovativen Unternehmen', Zeitschrift fuer Wirtschafts- und Sozialwissenschaften, 119, 561-592.

Almus, M. and S. Prantl (2000) 'Die ZEW-Gruenderstudie - Konzeption und Erhebung', Discussion Paper 00-60, Centre for European Economic Research (ZEW), Mannheim.

Almus, M., and S. Prantl (2001) 'Die Auswirkungen oeffentlicher Gruendungsfoerderung auf das Ueberleben und Wachstum junger Unternehmen', Discussion Paper 01-03, Centre for European Economic Research (ZEW), Mannheim.

Almus, M., D. Engel and S. Prantl (2000) 'The "Mannheim Foundation Panels" of the Centre for European Economic Research (ZEW)', Dokumentation 00-02, Centre for European Economic Research (ZEW), Mannheim.

Audretsch, D.B. (1995) Innovation and Industry Evolution. Cambridge: MIT Press.

Bates, T. (1990) 'Entrepreneur Human Capital Inputs and Small Business Longevity', Review of Economics and Statistics, 72, 551-559.

Birch, D.L. (1979) The Job Generation Process. M.I.T. Program on Neighbourhood and Regional Change, Cambridge.

Birch, D.L. (1987) Job Generation in America. New York.

Boeri, T., and U. Cramer (1991) 'Employment growth, incumbents and entrants. Evidence from Germany', International Journal of Industrial Organization, 10, 545-565.

Bruederl, J., and P. Preisendoerfer (2000) 'Fast growing businesses. Empirical evidence from a German study', International Journal of Sociology, 30, 45-70.

Bruederl, J., P. Preisendoerfer and R. Ziegler (1992) 'Survival chances of newly founded business organizations', American Sociological Review, 57, 227242 . 
Buergel, O., A. Fier, G. Licht and G. Murray (2000) 'Internationalisation of High-Tech Start-Ups and Fast-Growth Evidence for UK and Germany', Discussion Paper 00-35, Centre for European Economic Research (ZEW), Mannheim.

Curran, J. (1986) Bolton 15 Years on: A Review and Analysis of Small Business Research in Britain, 1971-1986. Small Business Research Trust, London.

Davis, S.J., J. Haltiwanger and S. Schuh (1996) Job Creation and Destruction, Cambridge, Mass.

Delmar, F. (1997), 'Mesuring Growth: Methodological Considerations and Empirical Results', in R. Donckels and A. Miettinen Eds., Entrepreneurship and SME Research: On its Way to the next Millenium, 199-216. Aldershot:Ashgate.

Dunne, T., M.J. Roberts and L. Samuelson (1989) 'The growth and failure of U.S. manufacturing plants', The Quarterly Journal of Economics, 96, 671-698.

Eisenhardt, K., and C. Schoonhoven (1990) 'Organizational Growth: Linking Founding Team, Strategy, Environment, and Growth among U.S. Semiconductor Ventures, 1978-1988', Administrative Science Quarterly, 35, 504-529.

Engel, D., and A. Fier (2000) 'Does R\&D-Infrastructure Attract High-Tech Start-Ups?', Discussion Paper 00-30, Centre for European Economic Research (ZEW), Mannheim.

Ericson, R., and A. Pakes (1995) 'Markov-perfect industry dynamics: a framework for empirical work', Review of Economic Studies, 62, 53-82.

Evans, D.S. (1987) 'The relationship between firm growth, size, and age: estimates for 100 manufacturing industries', The Journal of Industrial Economics, 35, 567-581.

Gehrke, B., H. Legler, V. Machate-Wei, U. Schasse, M. Steincke und F. Wagner (1997) 'Berichterstattung zur Technologischen Leistungsfaehigkeit', im Auftrag des Bundesministeriums fuer Bildung, Wissenschaft, Forschung und Technologie, Materialband, Hannover.

Hall, B.H. (1987) 'The relationship between firm size and firm growth in the US manufacturing sector', The Journal of Industrial Economics, 35, 583-606.

Harhoff, D., G. Licht, M. Beise, J. Felder, E. Nerlinger and H. Stahl (1996) Innovationsaktivitaeten kleinerer und mittlerer Unternehmen: Ergebnisse des Mannheimer Innovationspanels. Baden-Baden: NOMOS. 
Harhoff, D., K. Stahl and M. Woywode (1998) 'Legal form, growth and exit of West German firms - empirical results for manufacturing construction, trade and service industries', The Journal of Industrial Economics, 96, 453-89.

Harvey, A.C. (1976) 'Estimating regression models with multiplicative heteroscedasticity', Econometrica, 44, 461-65.

Jovanovic, B. (1982) 'Selection and the evolution of industry', Econometrica, 50, 649-70.

Licht, G., and E. Nerlinger (1998) 'New technology-based firms in Germany: a survey of the recent evidence', Research Policy, 26, 1005-22.

Lessat, V., and M. Woywode (1999) 'Schnell wachsende Unternehmen in Deutschland: Empirische Ergebnisse und politische Implikationen', in J. Merz ed., Existenzgruendung-Tips, Training, Studien, Praxis fuer Unternehmen und Freie Berufe. Baden-Baden: NOMOS.

McCullagh, P., and J.A. Nelder (1989) Generalized Linear Models. Vol.37 of Monographs on Statistics and Applied Probability, London: Chapman and Hall.

Nerlinger, E.A. (1998) Standorte und Entwicklung junger innovativer Unternehmen. Baden-Baden: NOMOS.

North D., and D. Smallbone (1995) 'Employment Generation and Small Business Growth in Different Geographical Environments', in F. Chittenden, M. Robertson and I. Marshall eds., Small Firms: Partnership for Growth. London: Paul Chapman, pp. 100-115.

Rajan, G.R., and L. Zingales (1998) 'Power in a theory of the firm', The Quarterly Journal of Economics, 113, 387-432.

Simon, H.A., and C.P. Bonini (1958) 'The size distribution of business firms', American Economic Review, 48, 607-17.

Steiner, V., E. Wolf, J. Egeln, M. Almus, H. Schrumpf and P. Feldotto (1998) Strukturanalyse der Arbeitsmarktentwicklung in den neuen Bundeslaendern. Baden-Baden: NOMOS.

Stiglitz, J.E. and A. Weiss (1981) 'Credit rationing im markets with imperfect information', The American Economic Review, 71, 393-410.

Storey, D.J. (1994) Understanding the small business sector, London: Routledge.

Storey, D.J. (1996) 'The Ten Percenters - Fast Growing SMEs in Great Britain', Research report, Deloitte \& Touche, London.

Sutton, J. (1997) 'Gibratss legacy', Journal of Economic Literature, 35, 40-59. 
Variyam, J.N, and D.S. Kraybill (1992) 'Empirical Evidence on Determinants of Firm Growth', Economics Letters, 38, 31-36.

Verbeek, M. (2000) A Guide to Modern Econometrics. New York: John Wiley \& Sons..

Wagner, J. (1992) 'Firm size, firm growth, and persistence of chance: testing GIBRATs law with establishment data from lower Saxony, 1978-1989', Small Business Economics, 4, 125-31.

Wagner, J. (1994) 'The post-entry performance of new small firms in German manufacturing industries', The Journal of Industrial Economics, 92, 14154 .

White, H. (1980), 'A heteroskedasticity-consistent covariance matrix estimator and a direct test for heteroskedasticity', Econometrica, 48, 817-38. 